Jurnal Ilmiah Farmasi (Scientific Journal of Pharmacy) 17(2) Agustus-Desember 2021, 115-126

ISSN: 1693-8666

available at http://journal.uii.ac.id/index.php/JIF

\title{
Cost consequences analysis of hypertensive outpatients: a study in a private hospital in Yogyakarta special province
}

\section{Cost consequences analysis antihipertensi pasien rawat jalan: studi di RS swasta Daerah Istimewa Yogyakarta}

\author{
Dinasari Bekti Pratidina ${ }^{1}$, Fithria Dyah Ayu Suryanegara ${ }^{1 *}$, Diesty Anita Nugraheni1
}

1Jurusan Farmasi, FMIPA Universitas Islam Indonesia

*Corresponding author: 106130101@uii.ac.id

\begin{abstract}
Background: Hypertension is a chronic disease that requires long-term treatment and has an impact on the cost of treatment. The costs will be greater given the loss of productivity, family burden, and social life impacted by hypertension based on patient's perspective.

Objective: The purpose of the study was to determine the costs and clinical outcome of antihypertensive therapy from the patient's perspective and to identify the discrepancies between the costs and the INA-CBGs (Indonesia Case Based Groups) tariff.

Methods: The research was an observational study with a cross-sectional design. The targeted population was outpatients who had received antihypertensive therapy for at least 1 month at a private hospital in Yogyakarta. The costs included direct medical costs, direct non-medical costs, and indirect costs, while the clinical outcomes were patient's blood pressure. The descriptive analysis was carried out to describe the characteristics of the research subjects, the clinical outcome, and the cost. Analysis of the discrepancies between the costs and the INA-CBGs tariff used the Mann-Whitney test and One-Sample t-test.

Results: The results showed that the average direct medical costs, direct non-medical costs, and indirect costs from the patient's perspective were IDR359,408.00, IDR24,617.00, and IDR 40,583.00, respectively. There was a significant difference between the real costs and the rate of INA-CBGs based on the results of statistical tests, while the cost discrepancy was IDR5,287,045.00.

Conclusion: The direct non-medical costs and indirect costs of hypertensive outpatients were less than the direct medical costs. A significant difference occurred between the real costs and INA CBG's tariff.
\end{abstract}

Keywords: hypertension, cost consequences, pharmacoeconomic, patient's perspective

\section{Intisari}

Latar belakang: Hipertensi termasuk penyakit kronis yang membutuhkan waktu pengobatan panjang dan biaya besar. Biaya akan lebih besar karena pasien kehilangan produktivitas, beban pada kehidupan keluarga dan masyarakat akibat penyakit hipertensi berdasarkan perspektif pasien.

Tujuan: Penelitian bertujuan untuk mengetahui gambaran biaya dan outcome terapi antihipertensi berdasarkan perspektif pasien serta kesesuaian biaya riil dengan tarif INA-CBGs.

Metode: Desain penelitian adalah observasional dengan rancangan cross-sectional. Populasi penelitian adalah pasien hipertensi rawat jalan di satu rumah sakit swasta Yogyakarta yang menerima terapi antihipertensi selama minimal 1 bulan. Analisis deskriptif digunakan untuk menggambarkan karakteristik subjek penelitian, outcome terapi, dan biaya terapi. Analisis kesesuaian biaya riil dengan tarif INA-CBGs dengan uji statistik Mann Whitney dan One Sample t-test.

Hasil: Hasil penelitian menunjukkan rata-rata biaya langsung medis, biaya non medis langsung, dan biaya tidak langsung berdasarkan perspektif pasien berturut-turut adalah Rp.359.408,00; Rp.24.617,00; dan Rp.40.583,00. Outcome terapi tertinggi ditunjukkan antihipertensi tunggal Calcium Channel Blocker (CCB) $(60 \%)$. Terdapat perbedaan secara statistik antara biaya riil dengan tarif INA-CBGs $(p=0,009$ dan $p=0,004)$ dan selisih biaya sebesar (Rp.5.287.045,00).

Kesimpulan: Biaya nonmedis langsung dan biaya tidak langsung pasien hipertensi rawat jalan tidak sebesar biaya medis langsung. Perbedaan signifikan antara biaya riil dan tarif INACBG's menjadi bahan evaluasi 
116| Dinasari, B. dkk /Jurnal Ilmiah Farmasi (Scientific Journal of Pharmacy) 17(2) Agustus-Desember 2021, $115-126$

perbaikan tarif INACBG's bagi BPJS Kesehatan. Hasil tersebut juga memicu pihak rumah sakit untuk melakukan evaluasi terhadap clinical pathway agar dapat memberikan terapi yang lebih efektif dan efisien.

Kata kunci: hipertensi, cost consequences, farmakoekonomi, perspektif pasien

\section{Pendahuluan}

Hipertensi merupakan kondisi klinis yang ditandai dengan terjadinya peningkatan tekanan darah sistolik hingga $\geq 140 \mathrm{mmHg}$ dan tekanan darah diastolik hingga $\geq 90 \mathrm{mmHg}$ dan terjadi secara persisten (DiPiro et al., 2015). Gejala dan tanda hipertensi jarang disadari oleh penderita sehingga berdampak pada terlambatnya penanganan dan diagnosis pasien hipertensi (WHO, 2013). Hipertensi erat kaitannya dengan resiko gangguan kardiovaskuler pada peningkatan setiap 20/10 $\mathrm{mmHg}$ tekanan darah (Zeind \& Michael, 2018).

Indonesia masih memiliki tugas besar dalam menangani hipertensi. Data yang diperoleh dari Riset Kesehatan Dasar (Riskesdas) tahun 2018 menunjukkan >34\% penduduk Indonesia menderita hipertensi (Kemenkes, 2019). Peningkatan prevalensi hipertensi diakibatkan oleh berbagai faktor diantaranya pertumbuhan penduduk, umur, dan gaya hidup seperti asupan makanan yang tidak sehat, penyalahgunaan alkohol, kurangnya aktivitas fisik, berat badan berlebih, serta stress yang terus menerus (WHO, 2013).

Hipertensi termasuk dalam penyakit kronis dengan waktu pengobatan yang cenderung panjang sehingga biaya yang dikeluarkan oleh pasien akan semakin meningkat (Sumiati et al., 2018). Biaya tersebut akan menjadi lebih besar jika ditambah dengan biaya terganggunya produktivitas, kehidupan keluarga, dan kehidupan sosial. Biaya terapi terbesar yang dibutuhkan oleh pasien hipertensi adalah biaya obat-obatan (Aizuddin et al., 2014).

Hipertensi telah memakan rata-rata biaya medis langsung pasien rawat jalan rumah sakit pada penggunaan kaptopril dengan diagnosis hipertensi tanpa penyakit penyerta sebesar Rp. 134.715.41,- sedangkan pada Lisinopril sebesar Rp. 315.093,16,-. Data pada penelitian yang sama menunjukkan besar biaya medis langsung untuk diagnosis hipertensi disertai penyakit penyerta Diabetes Melitus dengan penggunaan kaptopril adalah Rp. 242.320,- dan Lisinopril sebesar Rp. 492.270,- (Nugraheni \& Andayani, 2015).

Ilmu farmakoekonomi dapat membantu dalam membuat keputusan pada pengobatan dengan biaya yang tinggi karena mampu menjawab besar biaya tambahan yang dibutuhkan pada setiap peningkatan manfaat terapi (Rascati, 2014). Cost-consequence analysis merupakan salah satu metode kajian farmakokeonomi yang bertujuan untuk menggambarkan besar biaya pada suatu outcome terapi tanpa melakukan perhitungan maupun perbandingan efektivitas (Andayani, 2013). Konteks kajian farmakoekonomi di Indonesia masih banyak menggunakan perspektif penyedia layanan 
117| Dinasari, B. dkk /Jurnal Ilmiah Farmasi (Scientific Journal of Pharmacy) 17(2) Agustus-Desember 2021, $115-126$

kesehatan dimana tidak memperhitungkan biaya lain yang dibebankan kepada pasien diantaranya biaya langsung non medis dan biaya tidak langsung. Hal ini menunjukkan pentingnya cost consequences analysis penggunaan antihipertensi pada pasien rawat jalan di RS swasta Daerah Istimewa Yogyakarta (DIY).

\section{Metode}

\subsection{Deskripsi bahan dan teknik pengumpulan sampel}

Subjek penelitian adalah populasi terjangkau pasien hipertensi rawat jalan berdasarkan kriteria inklusi dan ekslusi. Kriteria inklusi antara lain adalah pasien dengan diagnosis hipertensi dan menjalani rawat jalan; telah menerima terapi antihipertensi minimal satu bulan sebelum pengambilan data berlangsung; serta menandatangani informed consent sebagai bentuk persetujuan. Adapun kriteria ekslusi adalah data pasien tidak lengkap baik data laboratorium, biaya, maupun obat.

\subsection{Penjelasan mengenai deskripsi jalannya penelitian}

Desain penelitian yang digunakan berupa model observasional analitik dengan rancangan cross-sectional dan berlangsung pada bulan Februari-Maret 2019 di salah satu RS swasta Daerah Istimewa Yogyakarta. Penelitian ini telah lolos uji kelaikan etik yang dilakukan oleh Komite Etik Penelitian Kedokteran dan Kesehatan Fakultas Kedokteran Universitas Islam Indonesia dengan nomor 59/Ka.Kom.Et/70/KE/II/2019. Penelitian telah disetujui oleh bagian Litbang RS swasta DIY dilanjutkan dengan pengambilan data secara langsung kepada pasien dengan teknik wawancara untuk memperoleh data biaya nonmedis langsung dan biaya tidak langsung. Pengambilan data karakteristik pasien dan outcome terapi dilakukan di Instalasi Rekam Medik, sedangkan data biaya medis langsung diperoleh di Bagian Keuangan RS swasta DIY. Outcome terapi ditentukan berdasar persentase jumlah pasien yang mencapai tekanan darah terkendali dibagi seluruh pasien dengan terapi antihipertensi pada golongan yang sama.

Perspektif penilaian pada kajian farmakoekonomi berpengaruh pada jenis biaya yang disertakan dalam perhitungan. Biaya yang dihitung berdasarkan perspektif pasien diantaranya biaya medis langsung, biaya non medis langsung, dan biaya tidak langsung. Biaya medis langsung yang disertakan dalam perhitungan diantaranya biaya obat antihipertensi, biaya obat penyakit penyerta, biaya laboratorium, dan biaya administrasi. Biaya non medis langsung meliputi biaya transportasi, konsumsi, dan parkir. Biaya tidak langsung merupakan biaya hilangnya produktivitas yang dihitung berdasarkan metode human capital. Analisis deskriptif dilakukan dalam bentuk mean dan persentase untuk menggambarkan karakteristik subjek penelitian (jenis kelamin, usia, tingkat pendapatan, 
118| Dinasari, B. dkk /Jurnal Ilmiah Farmasi (Scientific Journal of Pharmacy) 17(2) Agustus-Desember 2021, $115-126$

pekerjaan, durasi hipertensi, dan penyakit penyerta) outcome terapi, serta biaya. Kesesuaian biaya riil yang harus dikeluarkan oleh Rumah Sakit dengan tarif INA-CBGs dapat diketahui dengan membandingkan besar biaya riil yang harus dikeluarkan oleh Rumah Sakit selama 7 dan 23 hari dengan tarif INA-CBGs dan biaya penyakit kronis kemudian dilakukan analisis secara statistika menggunakan uji statistika One Sample t-test dan Mann Whitney.

\section{Hasil dan pembahasan}

\subsection{Karakteristik sosiodemografi pasien}

Hasil penelitian mengenai karakteristik pasien hipertensi rawat jalan di RS swasta DIY yang terangkum di dalam tabel di bawah ini.

Tabel 1. Karakteristik sosiodemografi pasien rawat jalan RS swasta DIY

\begin{tabular}{|c|c|c|c|}
\hline & Karakteristik Responden & Jumlah (n) & Persentase (\%) \\
\hline \multirow[t]{2}{*}{ Jenis Kelamin } & Perempuan & 73 & 63,48 \\
\hline & Laki-laki & 30 & 29,13 \\
\hline \multirow[t]{6}{*}{ Usia } & 15-24 tahun & 0 & 0,00 \\
\hline & 25-34 tahun & 1 & 0,97 \\
\hline & 35-44 tahun & 7 & 6,80 \\
\hline & 45-54 tahun & 25 & 24,27 \\
\hline & 55-64 tahun & 29 & 28,16 \\
\hline & $\geq 65$ tahun & 41 & 39,81 \\
\hline \multirow[t]{4}{*}{ Tingkat Pendidikan } & Tidak Sekolah & 5 & 4,85 \\
\hline & Pendidikan Dasar & 14 & 13,59 \\
\hline & Pendidikan Menengah & 47 & 45,63 \\
\hline & Pendidikan Tinggi & 37 & 35,92 \\
\hline \multirow[t]{14}{*}{ Pekerjaan } & Ibu Rumah Tangga & 35 & 33,98 \\
\hline & Pensiunan & 31 & 30,10 \\
\hline & Wiraswasta & 11 & 10,68 \\
\hline & Karyawan Swasta & 6 & 5,83 \\
\hline & PNS & 6 & 5,83 \\
\hline & Buruh & 3 & 2,91 \\
\hline & Guru & 2 & 1,94 \\
\hline & Petani & 2 & 1,94 \\
\hline & Supir & 1 & 0,97 \\
\hline & Entertainer & 1 & 0,97 \\
\hline & Tunakarya & 1 & 0,97 \\
\hline & ART & 1 & 0,97 \\
\hline & POLRI & 1 & 0,97 \\
\hline & Penjahit & 1 & 0,97 \\
\hline
\end{tabular}


119| Dinasari, B. dkk /Jurnal Ilmiah Farmasi (Scientific Journal of Pharmacy) 17(2) Agustus-Desember 2021, $115-126$

\begin{tabular}{|c|c|c|c|c|}
\hline \multicolumn{3}{|c|}{ Karakteristik Responden } & Jumlah (n) & Persentase (\%) \\
\hline \multicolumn{3}{|c|}{ Perawat } & 1 & 0,97 \\
\hline \multirow[t]{3}{*}{ Tingkat Pendapatan } & \multicolumn{2}{|l|}{$<1.000 .000$} & 39 & 37,86 \\
\hline & \multicolumn{2}{|c|}{$1.000 .000-2.500 .000$} & 29 & 28,16 \\
\hline & \multicolumn{2}{|c|}{$>2.500 .000$} & 35 & 33,98 \\
\hline \multirow[t]{3}{*}{ Durasi Hipertensi } & \multicolumn{2}{|l|}{$<1$ tahun } & 11 & 10,68 \\
\hline & \multicolumn{2}{|l|}{ 1-5 tahun } & 56 & 54,37 \\
\hline & \multicolumn{2}{|l|}{$>5$ tahun } & 36 & 34,95 \\
\hline \multirow{30}{*}{ Penyakit Penyerta } & \multicolumn{2}{|c|}{ Tanpa Penyakit Penyerta } & 19 & 18,45 \\
\hline & \multirow{12}{*}{$\begin{array}{l}1 \text { Penyakit } \\
\text { Penyerta }\end{array}$} & $\mathrm{DM}$ & 20 & 19,42 \\
\hline & & Dispepsia & 8 & 7,76 \\
\hline & & Polineuropati & 4 & 3,88 \\
\hline & & CHF & 3 & 2,91 \\
\hline & & Hiperlipidemia & 3 & 2,91 \\
\hline & & Hiperurisemia & 2 & 1,94 \\
\hline & & Asma & 1 & 0,97 \\
\hline & & Bronkitis & 1 & 0,97 \\
\hline & & CIHD & 1 & 0,97 \\
\hline & & Gonarthrosis & 1 & 0,97 \\
\hline & & Hiperkolesterolemia & 1 & 0,97 \\
\hline & & Arthrosis & 1 & 0,97 \\
\hline & \multirow{17}{*}{$\begin{array}{l}2 \text { Penyakit } \\
\text { Penyerta }\end{array}$} & DM+Hiperlipidemia & 11 & 10,68 \\
\hline & & DM+Dispepsia & 6 & 5,83 \\
\hline & & DM+Hiperurisemia & 2 & 1,94 \\
\hline & & CHF+Hiperurisemia & 1 & 0,97 \\
\hline & & CKD+Hiperurisemia & 1 & 0,97 \\
\hline & & Dislipidemia+Hiperurisemia & 1 & 0,97 \\
\hline & & Dispepsia+Angina Pectoris & 1 & 0,97 \\
\hline & & Dispepsia+Asma & 1 & 0,97 \\
\hline & & Dispepsia+Batuk & 1 & 0,97 \\
\hline & & Dispepsia+GERD & 1 & 0,97 \\
\hline & & Dispepsia+Hiperlipidemia & 1 & 0,97 \\
\hline & & Dispepsia+Hiperurisemia & 1 & 0,97 \\
\hline & & $\mathrm{DM}+$ Asma & 1 & 0,97 \\
\hline & & DM+Dislipidemia & 1 & 0,97 \\
\hline & & $\begin{array}{l}\text { DM+Disorder of Lipoprotein } \\
\text { Metabolism }\end{array}$ & 1 & 0,97 \\
\hline & & Gonarthrosis+Dispepsia & 1 & 0,97 \\
\hline & & $\begin{array}{l}\text { Gonarthrosis+Hiperkolestero } \\
\text { lemia }\end{array}$ & 1 & 0,97 \\
\hline
\end{tabular}


120| Dinasari, B. dkk /Jurnal Ilmiah Farmasi (Scientific Journal of Pharmacy) 17(2) Agustus-Desember 2021, $115-126$

\begin{tabular}{|c|c|c|c|}
\hline \multicolumn{2}{|c|}{ Karakteristik Responden } & \multirow{2}{*}{$\frac{\text { Jumlah (n) }}{1}$} & \multirow{2}{*}{$\begin{array}{c}\text { Persentase (\%) } \\
0,97\end{array}$} \\
\hline & $\begin{array}{l}\text { Hiperurisemia+Disorder of } \\
\text { Lipoprotein Metabolism }\end{array}$ & & \\
\hline & SLE+Bronkitis & 1 & 0,97 \\
\hline \multirow{3}{*}{$\begin{array}{l}3 \text { Penyakit } \\
\text { Penyerta }\end{array}$} & CKD+DM+Dispepsia & 1 & 0,97 \\
\hline & $\begin{array}{l}\text { Dispepsia+Hyperplasia of } \\
\text { Prostate+CHF }\end{array}$ & 1 & 0,97 \\
\hline & DM+CIHD+Hiperlipidemia & 1 & 0,97 \\
\hline \multicolumn{2}{|c|}{ Total Penyakit penyerta } & 84 & 81,55 \\
\hline
\end{tabular}

Keterangan: N = jumlah subjek setiap jenis karakteristik, PNS: Pegawai Negeri Sipil, ART: Asisten Rumah Tangga, POLRI: Polisi Republik Indonesia; DM = Diabetes Melitus tipe 2, CHF= Chronic Heart Failure, CIHD = Chronic Ingestive Heart Disease, $\mathrm{CKD}=$ Chronic Kidney Disease, GERD = Gastroesophageal Reflux Disease, $\mathrm{SLE}=$ Systemic Lupus Erythematosus

Hasil penelitian menunjukkan penderita hipertensi dengan jenis kelamin perempuan $(63,48 \%)$ lebih banyak dua kali lipat dibanding dengan pasien hipertensi laki-laki $(29,13 \%)$. Hal tersebut dapat terjadi karena perempuan mengalami penurunan kadar estrogen endogen ketika memasuki masa menopause, sehingga berdampak pada kelainan proses vasodilatasi dan disfungsi endothelium (Erdine et al., 2012). Hal tersebut diperkuat dengan diperoleh data usia pasien yang sebagian besar telah masuk dalam kelompok lanjut usia, yaitu sebesar 67.97\%. Prevalensi hipertensi yang tinggi pada kelompok usia di atas 50 atau 60 tahun disebabkan oleh kenaikan tekanan darah sistolik yang terus menerus, sehingga berdampak pada progresivitas kekakuan pembuluh darah (Weber et al., 2014).

Pada domain tingkat pendidikan, hasil penelitian menunjukkan mayoritas pasien memiliki tingkat pendidikan menengah (45,63\%). Peningkatan risiko hipertensi terhadap kelompok tingkat pendidikan rendah berhubungan dengan kemampuan pemahamam dan pengetahuan pasien tentang informasi terkait penyakit hipertensi, sehingga mempengaruhi pola hidup sehat yang juga akan berdampak pada peningkatan insidensi hipertensi (Anggara \& Prayitno, 2013). Karakteristik responden berdasarkan penghasilan menunjukkan mayoritas pasien hipertensi memiliki penghasilan kurang dari Rp. 1.000.000,00 setiap bulan (37,86\%). Pendapatan seseorang dapat berpengaruh terhadap kualitas daya beli yang dimiliki. Pendapatan yang rendah berdampak pada konsumsi yang kurang sehat, sehingga dapat meningkatkan resiko hipertensi (Vathesatogkit et al., 2012).

Karakteristik responden digolongkan berdasarkan penyakit penyerta, kelompok tanpa penyakit penyerta $(18,45 \%)$ dan dengan penyakit penyerta $(81,55 \%)$. Penyakit penyerta terbanyak adalah Diabetes Mellitus (DM). Hal tersebut dapat disebabkan pada kondisi hipertensi terjadi aktivasi sistem RAAS (Renin Angiotensin Aldosteron System) melalui aldosteron yang menyebabkan resistensi 
121| Dinasari, B. dkk /Jurnal Ilmiah Farmasi (Scientific Journal of Pharmacy) 17(2) Agustus-Desember 2021, $115-126$

insulin. Resistensi insulin merupakan salah satu penyebab terjadinya diabetes mellitus (Hsueh \& Wyne, 2011).

Berdasarkan profil terapi pasien hipertensi rawat jalan yang diperoleh, pola pengobatan yang paling banyak diberikan ialah antihipertensi dua kombinasi, khususnya golongan Angiotensin Receptor Blocker (ARB) dan Calcium Chanel Blocker (CCB). Pola pegobatan tersebut digunakan oleh 31 pasien dari total 103 (30,10\%). Kombinasi ARB dan CCB terbukti efektif dalam mengendalikan tekanan darah pada 80\% pasien hipertensi dan merupakan kombinasi golongan antihipertensi yang paling banyak digunakan (Weber et al., 2014). Kombinasi ARB dan CCB juga memiliki risiko kardiovaskuler paling rendah di antara kombinasi golongan obat lainnya dan menunjukkan perbaikan fungsi ginjal yang lebih baik dibanding dengan kombinasi obat golongan lain (Chi et al., 2016). Selain itu, penggunaan kombinasi ARB dan CCB dapat memberikan stabilitas tekanan darah yang baik pada pasien hipertensi dengan penyakit penyerta diabetes mellitus (Weber et al., 2014). Profil subjek penelitian berdasarkan penyakit penyerta menunjukkan jumlah pasien hipertensi dengan penyakit penyerta diabetes melitus memiliki persentase tertinggi dibanding penyakit lainnya. Hal tersebut yang kemudian mempengaruhi penggunaan kombinasi ARB dan CCB berada pada posisi paling banyak digunakan.

CCB tidak mempengaruhi sensitivitas insulin atau metabolisme glukosa sehingga dapat menjadi pilihan yang tepat pada pasien hipertensi dengan penyakit penyerta diabetes melitus (James et al., 2014). Hal ini yang kemudian menjadi penyebab tingginya ketercapaian outcome pada kelompok terapi antihipertensi tunggal CCB. Karakteristik subjek penelitian berdasarkan penyakit penyerta pada kelompok terapi tersebut menunjukkan 8 dari 15 pasien $(53,33 \%)$ menderita diabetes melitus. Pasien hipertensi dengan penyakit penyerta diabetes mellitus menurut JNC 8 (Joint National Committee 8) untuk usia < 60 tahun bukan kulit hitam direkomendasikan mendapatkan pengobatanawal mencakup diuretik tiazid, calcium channel blocker (CCB), angiotensin-converting enzyme (ACE) inhibitor, atau angiotensin receptor blocker (ARB) (Armstrong, 2014).

Tabel 2. Outcome terapi pada pasien hipertensi rawat jalan

\begin{tabular}{llcccc}
\hline \multicolumn{1}{c}{\begin{tabular}{c} 
Kelompok \\
\multicolumn{1}{c}{ Terapi }
\end{tabular}} & Golongan obat & $\begin{array}{c}\text { Jumlah } \\
\text { (n) }\end{array}$ & $\begin{array}{c}\text { Jumlah Pasien } \\
\text { Memenuhi } \\
\text { Target }\end{array}$ & $\begin{array}{c}\text { Persentase } \\
\text { Ketercapaian Terapi } \\
\text { (\%) }\end{array}$ \\
\hline $\begin{array}{l}\text { Antihipertensi } \\
\text { Tunggal }\end{array}$ & ARB & 21 & 7 & 33,3 \\
\cline { 2 - 5 } & CCB & 15 & 9 & 60,0 \\
\hline $\begin{array}{l}\text { Antihipertensi } \\
\text { Kombinasi } \\
\text { Obat }\end{array}$ & ARB+CCB & ARB+ $\beta$-Blocker & 31 & 10 & 32,3 \\
\cline { 2 - 5 } & ARB+Diuretik & 4 & 2 & 50,0 \\
\hline
\end{tabular}


122| Dinasari, B. dkk /Jurnal Ilmiah Farmasi (Scientific Journal of Pharmacy) 17(2) Agustus-Desember 2021, $115-126$

\begin{tabular}{|c|c|c|c|c|}
\hline & ACEI+Diuretik* & 1 & 1 & 100,0 \\
\hline Antihipertensi & ARB+Diuretik+CCB & 7 & 3 & 42,9 \\
\hline \multirow{3}{*}{$\begin{array}{l}\text { Kombinasi } 3 \\
\text { Obat }\end{array}$} & $\mathrm{ARB}+\mathrm{CCB}+\beta$-Blocker & 6 & 3 & 50,0 \\
\hline & ARB+ Diuretik+ $\beta$-Blocker & 4 & 2 & 50,0 \\
\hline & ARB+CCB+ Agonis $\alpha$-sentral* & 2 & 0 & 0,0 \\
\hline Antihipertensi & Diuretic+ $\beta$-Blocker $+\mathrm{ARB}+\mathrm{CCB}$ & 3 & 1 & 33,3 \\
\hline \multirow{3}{*}{$\begin{array}{l}\text { Kombinasi } \\
\text { Obat }\end{array}$} & ACEI+Diuretik+ CCB+ Agonis $\alpha$-sentral* & 1 & 1 & 100,0 \\
\hline & Diuretik+ ARB+ ACEI+ CCB* & 1 & 1 & 100,0 \\
\hline & $\beta$-Blocker+ARB+CCB+Agonis $\alpha$-sentral* & 2 & 0 & 0,0 \\
\hline Total & & 103 & 41 & 39,8 \\
\hline
\end{tabular}

Keterangan: $\mathrm{n}=$ jumlah subjek setiap kelompok terapi, $\mathrm{ARB}=$ Angiotensin Receptor Blocker, $\mathrm{CCB}=$ Calcium Chanel Blocker, ACEI = Angiotensin Converting Enzyme Inhibitor .

*=Kelompok terapi tidak disertakan dalam perhitungan

Rata-rata biaya medis langsung pasien hipertensi rawat jalan RS swasta DIY pada bulan Maret 2019 adalah Rp.359.408,00 dengan komponen biaya medis langsung yang paling besar berupa biaya terapi penyakit penyerta $(37,08 \%)$. Besaran tersebut dipengaruhi oleh penyakit penyerta yang diderita pasien diantaranya diabetes melitus tipe 2, gagal ginjal kronik, dan berbagai gangguan kardiovaskular. Salah satu penyakit penyerta seperti diabetes melitus tipe 2 merupakan penyakit kronis yang membutuhkan biaya terapi paling besar dibandingkan dengan penyakit penyerta lainnya.

Biaya non medis langsung yang peneliti perhitungkan pada penelitian diantaranya adalah biaya transportasi pasien menuju layanan kesehatan, biaya konsumsi pasien selama menjalani terapi, dan biaya parkir kendaraan pasien. Hasil penelitian menunjukkan besaran biaya untuk masingmasing komponen adalah sebesar Rp. 13.398,00; Rp. 9.626,00 ; dan Rp. 1.592,00. Biaya transportasi menjadi biaya yangdikeluarkan oleh seluruh pasien rawat jalan diakibatkan pasien rawat jalan pasti membutuhkan biaya transportasi menuju fasilitas layanan kesehatan karena seluruh pelayanan medis dilakukan tanpa menginap.

Total biaya berdasarkan perspektif pasien menunjukkan bahwa setiap pasien hipertensi rawat jalan di RS swasta DIY harus mengeluarkan biaya sebesar Rp. 424.607,00. Total biaya terbesar ditunjukkan oleh biaya medis langsung dengan rata-rata Rp.359.408,00 (84,64\%). Total biaya terbesar ditunjukkan oleh antihipertensi dengan kombinasi 4 golongan obat yaitu Diuretik, ARB, CCB, dan ACEI dengan besar biaya Rp. 1.435.153,00. Total biaya yang telah ditunjukkan pada tabel 3 berbeda dengan penelitian sebelumnya yang menyatakan besaran rata-rata biaya terapi antihipertensi berjumlah Rp.226.497,00 sedangkan pada tabel 3 tercantum biaya yang terkesan lebih besar yaitu Rp. Rp.411.079,00. Hal ini dapat disebabkan karena perbedaan perspektif yang digunakan pada penelitian sebelumnya. Perspektif yang digunakan pada penelitian tersebut berdasarkan pada perspektif penyedia layanan kesehatan dengan rata-rata biaya terapi merupakan akumulasi dari 
123| Dinasari, B. dkk /Jurnal Ilmiah Farmasi (Scientific Journal of Pharmacy) 17(2) Agustus-Desember 2021, 115-126

komponen biaya medis langsung tanpa menyertakan biaya non medis langsung dan biaya tidak langsung (Ernawati, 2016).

Tabel 3. Total biaya terapi pasien hipertensi rawat jalan

\begin{tabular}{|c|c|c|c|c|}
\hline $\begin{array}{c}\text { Komponen Tarif berdasarkan } \\
\text { Jenis Biaya }\end{array}$ & $\begin{array}{c}\text { JKN Non PBI } \\
n=92 \\
\text { (Rp; mean } \pm \text { SD) }\end{array}$ & $\begin{array}{c}\text { JKN PBI } \\
n=8 \\
\text { (Rp; mean } \pm \\
\text { SD) }\end{array}$ & $\begin{array}{c}\text { Umum } \\
n=3 \\
\text { (Rp; mean } \pm \\
\text { SD) }\end{array}$ & $\begin{array}{c}\text { Total } \\
\mathrm{n}=103 \\
(\mathrm{Rp} ; \text { mean } \pm \\
\text { SD) }\end{array}$ \\
\hline \multicolumn{5}{|l|}{ Biaya Medis Langsung } \\
\hline Biaya Obat Hipertensi & $\begin{array}{c}119.611 \pm \\
108.598\end{array}$ & $\begin{array}{l}94.875 \pm \\
85.270\end{array}$ & $\begin{array}{l}30.833 \pm \\
16.166\end{array}$ & $\begin{array}{c}115.104 \pm \\
106.231\end{array}$ \\
\hline Biaya Obat Penyakit Penyerta & $\begin{array}{c}126.065 \pm \\
224.853\end{array}$ & $\begin{array}{c}166.947 \pm \\
143.700\end{array}$ & $\begin{array}{l}41.140 \pm \\
36.086\end{array}$ & $\begin{array}{c}126.766 \pm \\
216.545\end{array}$ \\
\hline Biaya Administrasi & $20.000 \pm 0$ & $20.000 \pm 0$ & $20.000 \pm 0$ & $20.000 \pm 0$ \\
\hline Biaya Laboratorium & $55.000 \pm 0$ & $55.000 \pm 0$ & $55.000 \pm 0$ & $55.000 \pm 0$ \\
\hline Biaya Dokter & $46.065 \pm 73.426$ & $\begin{array}{c}14.938 \pm \\
12.369\end{array}$ & $\begin{array}{l}7.967 \pm \\
13.799\end{array}$ & $\begin{array}{l}42.538 \pm \\
70.216\end{array}$ \\
\hline Total Biaya Medis & 33.740 .143 & 2.814 .076 & 464.820 & 37.019 .039 \\
\hline Total tarif INA-CBGs & 17.516 .800 & 1.523200 & & \\
\hline $\begin{array}{l}\text { Total Biaya Penyakit Kronis ( } 23 \\
\text { Hari) }\end{array}$ & 10.944 .297 & 1.102 .521 & & \\
\hline Selisih Biaya & 5.279 .046 & 188.355 & & \\
\hline \multicolumn{5}{|l|}{ Biaya Non Medis Langsung } \\
\hline Biaya Transportasi & $13.587 \pm 12.008$ & $\begin{array}{c}12.500 \pm \\
11.339\end{array}$ & $10.000 \pm 0$ & $\begin{array}{c}13.398 \pm \\
11.743\end{array}$ \\
\hline Biaya Konusmsi & $9.853 \pm 8.788$ & $5.000 \pm 7.559$ & $\begin{array}{c}15.000 \pm \\
13.229 \\
\end{array}$ & $9.626 \pm 8.878$ \\
\hline Biaya Parkir & $1.522 \pm 1.084$ & $1.750 \pm 707$ & $3.333 \pm 1.155$ & $1.592 \pm 1.098$ \\
\hline \multicolumn{5}{|l|}{ Biaya Tidak Langsung } \\
\hline Loss of productivity & $45.163 \pm 186.199$ & $3.125 \pm 8.839$ & $0 \pm 0$ & $\begin{array}{l}40.583 \pm \\
176.391\end{array}$ \\
\hline
\end{tabular}

Keterangan:JKN= Jaminan Kesehatan Nasional; PBI=Penerima Bantuan Iuran.

Hasil uji statistika menggunakan One Sample t-test dan Mann Whitney test menunjukkan nilai signifikansi (P) pada perbandingan biaya riil yang dikeluarkan oleh rumah sakit dalam paket 7 hari 
124| Dinasari, B. dkk /Jurnal Ilmiah Farmasi (Scientific Journal of Pharmacy) 17(2) Agustus-Desember 2021, $115-126$

dengan Tarif INA-CBGs dan biaya obat 23 hari dengan tarif NonINA-CBGs masing-masing berada pada angka 0,009 dan 0,004. Hal tersebut menunjukkan bahwa besaran biaya medis langsung dari rumah sakit berbeda signifikan jika dibandingkan dengan tarif INACBG's yang diberlakukan oleh BPJS Kesehatan. Hasil tersebut dapat dipengaruhi oleh perbedaan harga obat yang digunakan oleh rumah sakit dan harga obat yang tertera pada e-catalogue. Peraturan terkait biaya obat penyakit kronis disebutkan bahwa biaya riil pengobatan selama 30 hari dibagi menjadi biaya riil 7 hari dan 23 hari. Biaya pengobatan riil selama 7 hari akan diklaim oleh BPJS kesehatan sebesar tarif INA-CBGs untuk penyakit kronis kecil lain-lain, sedangkan biaya pengobatan riil khusus obat kronis selama 23 hari akan diklaim terpisah berdasarkan harga dasar e-catalogue ditambah biaya pelayanan (Kemenkes, 2016).

Perbedaan biaya riil yang dikeluarkan oleh RS dan klaim BPJS dilakukan dengan menghitung selisih antara biaya riil dan klaim yang dibayarkan oleh BPJS. Hasil penelitian menunjukkan besar biaya riil yang lebih besar dibanding klaim BPJS dengan selisih Rp. 5.342.123,00 untuk 103 pasien hipertensi rawat jalan. Selisih pada perbandingan biaya riil yang dikeluarkan oleh Rumah Sakit dan klaim BPJS menunjukkan Rumah Sakit menderita kerugian dari program Jaminan Kesehatan Nasional (JKN). Hal ini disebabkan harga obat yang digunakan pada biaya riil merupakan harga obat yang telah ditentukan oleh Rumah Sakit serta kemudian ditinjau melalui perspektif pasien dan harga tersebut berbeda dengan harga dasar yang tercantum pada e-catalogue. Data yang diperoleh di lapangan juga menunjukkan beberapa obat yang diresepkan pada pasien tidak sesuai dengan Formularium Nasional (FORNAS) seperti misalnya obat Irbesartan, Clonidine, Ambroksol serta berbagai vitamin dan suplemen sehingga tidak dapat dihitung sebagai biaya klaim yang diperoleh Rumah Sakit. Kerugian yang sama juga terjadi pada kasus biaya riil pasien hipertensi primer rawat jalan JKN di rumah sakit swasta di Semarang, Jawa Tengah. Berdasarkan penelitian oleh Prabowo pada periode tahun 2017 di satu rumah sakit swasta di Semarang menunjukkan besarnya perbedaan antara biaya riil dengan tarif INA-CBGs yaitu Rp (-854.200) (Prabowo, 2018).

\section{Kesimpulan}

Hasil pada penelitian kali ini menunjukkan rata-rata biaya medis langsung, biaya non medis langsung, dan biaya tidak langsung pada terapi hipertensi di salah satu RS swasta di DIY berdasarkan perspektif pasien secara berurutan adalah Rp. 359.408,00; Rp. 24.617,00; dan Rp. 40.583,00. Outcome terapi hipertensi tertinggi ditunjukkan oleh antihipertensi tunggal CCB dengan nilai outcome 60\%. Perbedaan antara biaya riil yang dikeluarkan oleh Rumah Sakit dengan klaim BPJS untuk terapi hipertensi pada bulan Maret 2019 menunjukkan RS swasta DIY menderita kerugian sebesar Rp. 5.342.123,00 untuk 103 pasien hipertensi rawat jalan. 
125| Dinasari, B. dkk /Jurnal Ilmiah Farmasi (Scientific Journal of Pharmacy) 17(2) Agustus-Desember 2021, 115-126

\section{Daftar Pustaka}

Aizuddin, A. N., MN, A., Kang, T. W., AR, R., Hong, Y. G., A, A., I, A., WP, S. E., \& AM, M. R. (2014). Cost Analysis of Hypertension Management in an Urban Primary Medical Centre Kuala Lumpur. Malaysian Journal of Public Health Medicine, 14(3), 18-23.

Andayani, T. M. (2013). Farmakoekonomi Prinsip Dan Metodologi (1 ed.). Yogyakarta: Bursa Ilmu.

Anggara, F. H. D., \& Prayitno, N. (2013). Faktor-Faktor Yang Berhubungan dengan Tekanan Darah di Puskesmas Telaga Murni, Cikarang Barat Tahun 2012. Jurnal Ilmu Kesehatan Masyarakat, 5(1), 22.

Armstrong, C. (2014). JNC8 Guidelines for the Management of Hypertension In Adults. American Family Physician, 90(7), 503-504. Retrieved from https://www.aafp.org/afp/2014/1001/afp20141001p503.pdf

Chi, C., Tai, C., Bai, B., Yu, S., Karamanou, M., Wang, J., Protogerou, A., Blacher, J., Safar, M. E., Zhang, Y., \& Xu, Y. (2016). Angiotensin System Blockade Combined With Calcium Channel Blockers Is Superior to Other Combinations in Cardiovascular Protection With Similar Blood Pressure Reduction: A Meta-Analysis in 20,451 Hypertensive Patients. J Clin Hypertens (Greenwich), 18(8), 801-808. doi:10.1111/jch.12771

DiPiro, J. T., Talbert, R. L., Yee, G. C., Matzke, G. R., Wells, B. G., \& Posey, L. M. ( 2015). Pharmacotherapy: A Pathophysiologic Approach (9 ed.). New York: McGraw-Hill Medical.

Erdine, S., Arslan, E., \& Olszanecka, A. (2012). Hypertension in Women-Pathophysiological and Clinical Aspects. Przegl Lek, 69(2), 72-75.

Ernawati, Y. (2016). Analisis Efektifitas Biaya Penggunaan Antihipertensi Kombinasi Dua Obat Pada Pasien Hipertensi Rawat Jalan Di Rumah Sakit "X" Tahun 2012. (Bachelor). Universitas Muhammadiyah Surakarta, Surakarta.

Hsueh, W. A., \& Wyne, K. (2011). Renin-Angiotensin-aldosterone system in Diabetes and Hypertension. J Clin Hypertens (Greenwich), 13(4), 224-237. doi:10.1111/j.17517176.2011.00449.x

James, P. A., Oparil, S., Carter, B. L., Cushman, W. C., Dennison-Himmelfarb, C., Handler, J., Lackland, D. T., LeFevre, M. L., MacKenzie, T. D., Ogedegbe, O., Smith, S. C., Jr., Svetkey, L. P., Taler, S. J., Townsend, R. R., Wright, J. T., Jr., Narva, A. S., \& Ortiz, E. (2014). 2014 Evidence-based Guideline for the Management of High Blood Pressure in Adults: Report from the Panel Members Appointed to the Eighth Joint National Committee (JNC 8). Jama, 311(5), 507-520. doi:10.1001/jama.2013.284427

Kemenkes. (2016). Peraturan Menteri Kesehatan Republik Indonesia Nomor 52 Tahun 2016 tentang Standar Tarif Pelayanan Kesehatan dalam Penyelenggaraan Program Jaminan Kesehatan. Jakarta: Kementrian Kesehatan RI

Kemenkes. ( 2019). Laporan Nasional Riskesdas 2018. Jakarta: LP Balitbangkes

Nugraheni, D. A., \& Andayani, T. M. (2015). Cost-Minimization Analysis Captopril Versus Lisinopril Of Outpatients With Hypertension. Jurnal Farmasi Indonesia, 12(2), 179-189. doi:https://doi.org/10.31001/jfi.v12i2.91

Prabowo, W. (2018). Analisis Perbedaan Biaya Riil Rumah Sakit Dengan Tarif INA-CBG's untuk Kasus Penyakit Hipertensi Primer pada Pasien Era Jkn (Studi Kasus di RS Islam Sultan Agung Semarang Periode Januari 2017-Oktober 2017) (Bachelor). Universitas Islam Sultan Agung, Semarang. Retrieved from http://repository.unissula.ac.id/id/eprint/13387

Rascati, K. L. ( 2014). Essentials of Pharmacoeconomics (2 ed.). Philadelphia: Wolters Kluwer Health/Lippincott Williams \& Wilkins. 
Sumiati, L., Citraningtyas, G., \& Yudistira, A. (2018). Analisis Efektivitas Biaya Terapi Antihipertensi pada Pasien Hipertensi Rawat Inap di RSU Pancaran Kasih GMIM Manado. Pharmacon, 7(1), 1-9. doi:https://doi.org/10.35799/pha.7.2018.18723

Vathesatogkit, P., Woodward, M., Tanomsup, S., Hengprasith, B., Aekplakorn, W., Yamwong, S., \& Sritara, P. (2012). Long-term Effects of Socioeconomic Status on Incident Hypertension and Progression of Blood Pressure. J Hypertens, 30(7), 1347-1353. doi:10.1097/HJH.0b013e32835465ca

Weber, M. A., Schiffrin, E. L., White, W. B., Mann, S., Lindholm, L. H., Kenerson, J. G., Flack, J. M., Carter, B. L., Materson, B. J., Ram, C. V., Cohen, D. L., Cadet, J. C., Jean-Charles, R. R., Taler, S., Kountz, D., Townsend, R. R., Chalmers, J., Ramirez, A. J., Bakris, G. L., Wang, J., Schutte, A. E., Bisognano, J. D., Touyz, R. M., Sica, D., \& Harrap, S. B. (2014). Clinical Practice Guidelines for the Management of Hypertension in the Community: A Statement by the American Society of Hypertension and the International Society of Hypertension. J Clin Hypertens (Greenwich), 16(1), 14-26. doi:10.1111/jch.12237

WHO. (2013). A Global Briefon Hypertension, Silent Killer, Global Public Health Crisis.

Zeind, C., \& Michael, G. C. (2018). Applied Therapeutics : The Clinical Use of Drugs (11 ed.). Philadelphia: Wolters Kluwer Health. 